Journal. The leaders in the potato industry read this monthly publication and the crowd follows the leaders. If you wish to increase your sales advertise in the American Potato Journal. The rates are extremely low and liable to be advanced soon. Contract now for space. The present rates are:-

\begin{tabular}{|c|c|c|c|}
\hline & $\begin{array}{l}\text { For one } \\
\text { month }\end{array}$ & $\begin{array}{l}\text { Three months } \\
\text { per month }\end{array}$ & $\begin{array}{l}\text { Six months } \\
\text { per month }\end{array}$ \\
\hline cover page & $\$ 25.00$ & $\$ 22.50$ & $\$ 20.00$ \\
\hline pages & 20.00 & 18.00 & 16.00 \\
\hline lar pages & 15.00 & 13.50 & 12.00 \\
\hline ne-half page & 8.00 & 7.25 & 6.50 \\
\hline
\end{tabular}

You will get your share of sales by advertising in the American Potato Journal.

\title{
HAVE YOU PAID YOUR DUES?
}

In the February issue a notification was sent to 320 members informing them that their membership and subscription had expired. A part of this number have not yet responded to this appeal. Kindly send your check or postal money order payable to the Potato Association of America, 108 Baltimore Ave., Takoma Park, D. C. at your earliest convenience.

Active membership .............. $\$ 2.00$ per year

Associate membership ............. $\$ 1.00$ per year

The active members receive the American Potato Journal and the Annual Report. The Associate members receive the American Potato Journal.

"Procrastination is the thief of time."

\section{OREGON POTATO LAW}

Oregon is a pioneer in the United States in passing a bill dealing with the grading and certification of potatoes. The use of fraudulent certification tags in this state has made it necessary to have a law to protect both its producers and users of certified seed potatoes. Section 3 and 6 of this law are found on page 92 of this issue. Oregon deserves to be complimented on the move it has taken. But in reading it over and knowing what is taking place in other states we can see the advantages of having universal certification standard and law. If we are not on our guard we may have as many certification laws as there are certification standards. Under such conditions what may be legal in one state may not be in another state. The law governing certified seed should be the same throughout the United States and 